\title{
CHARACTER EDUCATION VALUES IN JAVANESE LITERATURE
}

\author{
Umi Masfiah ${ }^{1}$, Darweni ${ }^{2}$, Zakiyah ${ }^{1}$, Umi Muzayana ${ }^{1}$, \\ and Tauseef Ahmad Parray ${ }^{3}$ \\ ${ }^{1}$ Office of Religious Research and Development, Ministry of Religious \\ Affairs, Semarang, Indonesia \\ ${ }^{2}$ Reksa Pustaka Library, Mangkunegaran, Surakarta, Indonesia \\ ${ }^{3}$ Islamic Studies, Higher Education Department, Jammu and Kashmir, \\ India. \\ Email: masfiah.umi@gmail.com
}

Received: January 21, 2021

Accepted: May 18, 2021

\section{Abstract}

Javanese manuscripts as the legacy of ancestors and poets contain important values related to character education and moral values. Manuscript of Serat Wulang Darmawiya (SWD), for example, promotes character education through caring behavieor. The values of character education are fundamental to internalize and implement within the life of Javanese. Javanese poets in the past inherited the noble values through a lot of literary works. This article discusses the values of character education in SWD. Using text-based qualitative research methodology, the values of character education in SWD were analyzed with content analysis. manuscript teaches values of character education regarding the importance of breastfeeding as a process of building an intimate relationship between children and parents (mother). At the same time, it also explains the importance of communication between children and parents during education process, the principles of child education, the role model and advice from the parents to the children. In addition, the philosophy of SWD is closely integrated with Islamic teachings. 
Naskah-naskah Jawa peninggalan para leluhur dan para pujangga, sarat dengan nilai pendidikan karakter dan budi pekerti luhur. Naskah Serat Wulang Darmawiyata (SWD) memiliki keunikan pada penanaman nilai pendidikan karakter khas Jawa, yakni membentuk anak mandiri dan cerdas berdasarkan laku prihatin. Nilai-nilai pendidikan karakter bagi masyarakat Indonesia merupakan hal yang amat penting untuk dimiliki dan diterapkan dalam kehidupan berkeluarga dan bermasyarakat, demikian pula dengan masyarakat Jawa. Para pujangga Jawa masa lalu telah banyak mewariskan nilai-nilai luhur melalui berbagai karya dalam sastra Jawa. Artikel ini secara khusus membahas tentang nilai-nilai pendidikan karakter dalam SWD. Dengan menggunakan metode penelitian kualitatif berbasis teks sastra Jawa, naskah yang memiliki makna nilai-nilai pendidikan karakter dianalisis dengan metode analisis isi. Dalam serat tersebut, terdapat nilai-nilai pendidikan karakter tentang pentingnya menyusui sebagai proses kedekatan anak dengan orang tua (ibu). Selanjutnya dalam serat tersebut, dijelaskan pula tentang pentingnya pendidikan komunikasi anak dan orang tua, prinsip-prinsip mendidik anak, dan keteladan serta nasehat orang tua terhadap anak. Selain itu, bahwa falsafah dalam SWD memiliki hubungan atau terintegrasi dengan ajaran Islam.

Keywords: character education; Javanese literature; Serat Wulang Darmawiyata

\section{Introduction}

Character education is a fundamental element for Indonesian society in the context of the nation, religion, and even local culture that it needs to be internalized since childhood. In regard, Javanese poets write the values of character education in numerous books known as serat that contains the noble teachings of Javanese. Most of the works contain character education, such as Serat Kalatidha by Ranggawarsita (Purwadi, 2015), Serat Wedhatama by KGPAA Mangkunegara IV (Wiratini, 2017), Serat Wulangreh by Sri Susuhunan Pakubuwana IV (Retnowati, 2020), Serat Cebolek by Kiai Jasadipura I (Astuti, 2018), Serat Sana Sunu by Kiai Ngabehi Yasadipura II (Suhanjati, 2004), and Serat Centhini by Sunan Pakubuwana V (Wibawa, 2013). In addition, there are also the works of Kiai Sastradipura (Naif, 2016), Maswadiharjo, Raden Mas Wiryasusastro, Mas Reksatanaya, and Mas Prawiryasudirya (Khasani, 2015). They are productive in transferring the noble values of Javanese culture into literatures.

Therefore, this article explicitly discusses Serat Wulang Darmawiyata (SWD), which contains character education perceived as the inheritance of 
KGPAA Mangkunegara IV. Several reviews on character education in the Javanese literature have been previously written. (Deswijaya \& Nurnaningsih, 2016; Maknun, 2017; Ridlo, 2018; Mustolehudin, 2018; Masfiah, 2018). They examine character values within these manuscripts: Serat Kridhaswasita, Serat Wasitawala, Serat Wirid Wedharaning Cipta Sasmitaning Ngilmi, Suluk Seh Ngabdul Salam, and Serat Munasiat Jati. The illumination in the Javanese literary work titled Babad Pecina that takes a Javanese decoration, known as Rerenggan, of flower petals and crown, Deer, Bull Head, Banana Blossom, Dragon King, royal lamp, and Jamang Susun Tiga describes the values of leadership character education (Ekowati et al., 2017). It is the representation of a compelling, brave, humble, and pure-hearted leader. Also, the decoration asserts that a leader should possess a religious value, such as being obedient with God as the highest authority in the universe.

The character education in those Javanese manuscripts depicts that there are Islamic values in Javanese society. Mulyono and Sahlan, (2012) mention that Macapat songs in Javanese literatures written by Walisongo are media to disseminate Islam in Java. Thus Javanese philosophy embedded in Javanese ethic can be defined as part of the Islamic mysticism (Kholil, 2007; Rubaidi, 2019). It is similar to the SWD text that teaches character education for children based on Javanese philosophy, whose idea is also part of the Islamic teaching.

Aside from the above discussion, many Javanese manuscripts contain various themes like history, philosophy, Islamic teaching, horoscope, and others. Some of them have been discussed by previous scholars in Babad Kandha, Babad Kraton and its variation in Javanese literature (Day, 1978) and also in Kidung literature (Robson, 1979). How Javanese converted to Islam was explored in a manuscript called "A Book of Thousand Questions" (Ricci, 2009), and how Javanism met Islam presented the Serat Darmagandul (Drewes, 2013). The production of Javanese literary works in the nineteenth century was explored (Behrend, 1993) and examined in the work of K.P.H. Suryanagara (Behrend, 1999).

The previous studies prove that Javanese literary works contain important values of character education and other important aspects that should be reviewed since they reflect the characters of Javanese society. One of the Indonesian cultural practitioners, Mochtar Lubis, in 1977 mentioned that some of the poor traits of Indonesian are hypocritical, less responsible, feudal, superstitious capricious, extravagant, and shortcut-taking (Yahya, 2017).

el Harakah Jurnal Budaya Islam Vol. 23 No. 1 Tahun 2021 
The poor characters can also be found in Javanese literary work titled Serat Wulang Darmawiyata (SWD). They grow within Javanese children because during the childhood, they were breastfed by their mother too long. In addition, the content of SWD also mentions that good characters grow since breastfeeding period to the childhood and eventually until the children understand the good and bad teachings. The main characters of children to avoid are laziness and anxiety.

The advice or pitutur in regards with the formation of the child characters in SWD are essential to study. The advice and the teachings of building children's character in each phase of development play as tools for the parents to educate their children. Therefore, the current study completes the gap, which is about character education values for children since the early ages. Therefore, the current research investigates the procedures of building children's character during breastfeeding according to SWD, and the procedures of growing character values among children under five to pre adolescent according to SWD

\section{Method}

This article was written based on the research conducted in 2019 concerning the character education in the manuscript of SWD, translated by Darweni (2017), one of the librarian of Reksa Pustaka. It employed a qualitative research method with the historical approach and content analysis. Holsti (cited in Eriyanto, 2011), states that content analysis is implemented to answer the question of 'what, to whom, and how' from the communication process. The question word "what" is implemented to answer the content of a message, a trend, or any differences among the messages delivered from various communicators. Meanwhile, "to whom" is used to test the hypothesis about the content of the message proposed for public. "How" aims to describe the form and the technique of the message (Eriyanto, 2011). Moreover, a content analysis refers to "what has been apparent (heard, perceived, or read), but, the meaning refers to what has been implied, invisible, or directly heard." (Eriyanto, 2011). Similarly, content analysis refers to the concept of literature that has been used to uncover, understand, and capture the message of literary works (Endraswara, 2008).

Content analysis is performed in two ways, inference and data presentation analysis. Inference is the preliminary step before conducting analysis and systematically drawing an abstract conclusion (Endraswara, 2008). 
The subsequent step is performing data analysis. This stage analyzes a context related to the structure and the construct of the literary works.

Krippendorf suggests the following analysis: (1) defining unit of analysis; (2) defining unit of the sample; (3) defining unit of record; and (4) defining unit of context. Meanwhile, this article mainly concerns the concept of child character formation in SWD by reviewing the sentences and exploring the context and period of SWD creation (Krippendorff, 2004).

\section{Description of Serat Wulang Darmawiyata (SWD)}

Serat Wulang Darmawiyata (SWD) was written in Javanese language and script. A catalogue written by Florida (2000) mentions that Serat Wulang Darmawiyata is under a code; MN. 399 A. 83. SMP 67/20 with an anonymous author. The manuscript was written in Surakarta in 1862 or at the end of the $19^{\text {th }}$ Century. The size of the manuscript is $84: 33.30 \times 20.50 \mathrm{~cm}$. It belongs to a Javanese traditional poet named macapat.

The text contain "sinome kinarya mulang, pamulange lare cilik." Furthermore, it displays the teachings related to marriage, child-rearing practice, characters, and the reminders of family responsibility and Islam. The text of tembang, or Javanese folk song, was composed on 23 Dzulgangidah 1790 je or May $23^{\text {rd }}$, 1862 AD. The writer of SWD was unknown. Instead, there found only a stamp on the manuscript of SWD with the following handwriting: "Pangeran Harijo Gondohatmodjo. Mangkunegaran S.K." The manuscript of Piwulang (Darweni et all, 2016:56) mentions that SWD is stored in the Reksapustaka Library, Pura Mangkunegaran, Surakarta written on the European-type paper, with 90-page in length, and in a good condition. The size of the manuscript is $31.50 \times 20.00 \mathrm{~cm}$ with text size $25.00 \times 14.50 \mathrm{~cm}$.

\section{The History of Javanese Manuscripts}

The existence of Javanese manuscripts are closely associated with the history of the dissemination of Islam to Java. Islam was brought by businessmen through the coastal areas. They lived in a place known as Kauman, a complex of the settlement located nearby a mosque. They brought religious scriptures as their reading materials, which were copied and rewritten by them and the craftsmen nearby. Some of the manuscripts were inspired by the Arab-Persian culture such as Serat Anbiya (the Book of the Prophets) which contains the story of the Prophet Adam PBUH until that of the Prophet Muhammad SAW, Serat Raja Pirangon (the Book of Pharaoh), and Serat Johar Manikam 
which contain the story of the Princess of Baghdad who married the King of Persia. In addition, there are also several Malay-language manuscripts, such as Serat Ahmad Muhammad, Serat Abunawas, Serat Bagenda Seh Mardan (the Chronicle of Syah Mardan), Serat Yusup, Serat Abdurrahman Abdurrahim, and Serat Latikusuma (Ras, 2014).

Furthermore, many manuscripts were rewritten by royal palace through the royal poets under the support of Javanese kings. The power of Javanese, who had been taking a turn in serving the throne, could not eliminate the script-writing tradition (Simuh, 1999). KGPAA Mangkunegara I and his successors paid attention to the manuscripts inherited from their ancestors by maintaining and ordering Javanese literary manuscripts. In addition, people who lived in that era also participated in disseminating the Javanese literary manuscripts, as many people handed over their manuscripts to their kings. The manuscripts then become the collections of Reksa Pustaka Library Surakarta now.

\section{Socio-Historical Aspects of Serat Wulang Darmawiya (SWD)}

SWD was written at the end of the $19^{\text {th }}$ Century, according to colophon, specifically on Jumat Kliwon 23 bulan Dzulqaidah tahun 1790 je or May 23 $3^{\text {rd }}$, 1862 AD. It explains that "the text was completely composed on Jumat Kliwon, bulan Dzulkangidah, tanggal dua puluh tiga, tahun Je at that time. It was on 1790 as far as I remember" (Darweni, 2017: 31).

The above colophon mentions that it was written in $1862 \mathrm{AD}$ or at the end of the $19^{\text {th }}$ century. It was the time when Mangkunegara Palace was under the throne of KGPAA Mangkunegara IV. He had reigned Mangkunagara from 1864 until 1881 AD. His reign was at the golden age. Mangkunegara Palace could stand independently in economics, politics, and culture between Surakarta and Ngayogyakarta Hadiningrat Palace. The author mentions that the objective of composing SWD is to salvage the readers in terms of religion and to prevent them from misconducts. He writes:

"The poet prays the dearest readers that they may always be healthy, be redeemed by the religion, be avoided from misconducts, be in the path of righteousness, so that they remove all disasters" (Darweni, 2017: 4).

After reading SWD, readers are expected to understand religion, so they are safe, spare from any misconduct, and always guided to the righteousness. 


\section{Character Education in Serat Wulang Darmawiya (SWD)}

SWD contains the subject of family-based character formation for children. It suggests that such character grows since the early childhood especially during breastfeeding until the age of 11 . During the breastfeeding period, the mother should consider the weaning time, ideally at about 0-17 months (about two years). The breastfeeding period is recognized as the ideal period to build children characters, like building independency and intellectuality. On the other hand, they are weaned until three years old, they will have bad characters, such as being stupid and hard to be apprehensive.

SWD mentions that the phases of children's character development starts from five until seven years old. During the period, they should recognize good characters and know bad things to avoid. They should be free and directed. Then, during seven to eleven years old, parents should give more attention and be assertive. Parents should give clear direction what is allowed to do and what is not. All of the teachings of character education are based on the Javanese values. Moreover, the values are similar to those in Islam.

\section{Values of Education during Breastfeeding}

SWD suggests that breastfeeding can influence the children's character formation. Children who gain breastfeeding too long will be stupid, lazy, less apprehensive, and rebellious against their parents. The statement is written in the following Javanese traditional poem:

"Some people want to be rich but they do not want to be apprehensive just like the others. People who want to eat less but do not want to be apprehensive are equal to the fools and dwell in the dark because they only care about eating and drinking" (Darweni, 2017: 36).

The fools refer to the people who do not want to be apprehensive since they only care about eating and drinking, getting a too-long breastfeeding. following Javanese traditional poem confirms the statement:

"It is the characteristics of a child who is too long in the breastfeeding time will become stupid and lazy. Both boys and girls will not have merits in their life if they do not want to be apprehensive" (Darweni, 2017: 37)."

The situation is different from the children weaned during childhood. They will be clever and apprehensive. Weaning children is suggested in the following poem:

"Children will be troublesome and stupid. Although they are smart, they only have few merits in their life and their mind is more inclined to the misconducts since they do not want to be apprehensive. But for the children who have been 
weaned during their childhood, they shall be clever and more apprehensive" (Darweni, 2017: 38).

In addition to being lazy, stupid, and less apprehensive, children who gain a too-long breastfeeding will be rebellious against their parents. They will find difficulties returning the kindness of their parents, such as massaging or feeding their mother. Also, they will not attain a high quality of life. They usually come from the villages. A poem writes:

"If the children are in their breastfeeding time for a long time, then they will be insubordinate and be rebellious toward their parents. It is very difficult for them to return to their parents' kindness, such as massaging or feeding their mother, and they will be far away from attaining a higher degree in their life. These children usually come from the villages" (Darweni, 2017: 40).

According to SWD, the criminals in the world have been breast-fed too long in their childhood, and they are less apprehensive as well. The following poem explains:

"Usually, in this world, the criminals are everywhere and they have been too long in their breastfeeding time. People who have been a robber and doing misconducts for a long time must have been too long in their breastfeeding time and must have also been less apprehensive" (Darweni, 2017: 42).

Furthermore, it also describes that the children who have been too long in their breastfeeding time internalize little knowledge. They do not understand religious knowledge and cannot internalize ilmu rahsa (knowledge of introspection). This situation is found in the following poem:

"That explains why these children internalize little knowledge. The children who were too long in their breastfeeding time will internalize little knowledge and not understand religion's knowledge. If they learn about the secret knowledge (ilmu rahsa) it will be like heaven and earth and the situation will be the same when they learn about kindness" (Darweni , 2017:43).

The children who were weaned a little bit late will find difficulties in attaining success especially in terms of occupation even though many jobs, such as gardening, trading, and farming activities, are available. On the contrary, children who are weaned earlier will be more alert and smarter to be success.

"The children who were weaned later will have difficulties. There are many ways to gain glory such as gardening. In the beginning, it is difficult because people will be hungry, but, in the end, they will be full. This kind of situation will only be found among people who exercise their body" (Darweni et. all, 2016:44).

Kinira-kira keni, wiweka manah grahita, kang sugih lawan miskine, ulaha kadursilan, adaganga tanena, yen kanga nom susonipun, wiwek manah grahita (Pupuh Asmarandhana, nd.:75). 
"Problems are unpredictable and it is a part of the alert in our mind, for both the rich and the poor, in terms of doing misconducts, trading, and farming. For the children who have been weaned earlier, they will be alert and smart" (Darweni, 2017: 38).

Late breastfeeding may also lead to being unemployed, breaking plates, breaking bowls, breaking mortars, breaking jugs, losing knives, scratching buildings, scratching clothes, talking too much, saying bad words, and shy. As they grow up, they usually become bearers.

Tan wande ngewang-ngewangi, rare katuwan sesepan, destun saanggur-anggure, mecahaken piring pinggan cowek kendhi, myang layah, ngilangaken pangot wedhung, bedhakaken sasandhangan (Pupuh Asmarandhahana, nd.:76).

"No one can change the fate of the children who are too long in their breastfeeding time. They will be fond of being unemployed, breaking plates and bowls, breaking mortars, breaking jugs, losing knives, scratching buildings, and scratching clothes" (Darweni, 2017: 38).

\section{The Ideal Time for Breastfeeding}

Parents are responsible for shaping their children to be intelligent, cautious, and apprehensive with self-control skill to be reach a successful life. They can educate the children since the infancy period, during the breastfeeding time, and several months after the children are weaned. SWD suggests that the ideal breastfeeding time is between 0-7 months and 17 months:

"Therefore, when they are still young, the children should be weaned, specifically at around eighth, ninth, tenth, eleventh, twelfth, thirteenth, fourteenth, fifteenth, sixteenth, and seventeenth month."

The children who are weaned earlier in their infancy (within 7 to 17 months after their birth) will be apprehensive with a good self-control, and they attain a higher quality in life:

"But for the children who are weaned earlier in their infancy, they will be more apprehensive and more able to control themselves. Therefore, they will attain the higher degree. On the other hand, people who are fond of committing misconducts are too long in their breastfeeding time. If the children are weaned earlier in their infancy, they will not be evil" (Darweni, 2017: 41).

The concept of the ideal breastfeeding time, which is between 7-17 months in the SWD, is in line with that outlined in Al-Qur'an, which is 2 years. It is suggested in Surat Lukman: 14 and Surat al-Baqarah: 233, which translate:

"And We instruct to human being to do a good deed to their partners - their mother who are pregnant in a weak condition, and she becomes weaker and weaker, and the weaning is in two years - Give thanks to Me and their parents. Me is a place to come back." (Q.S (31) Verse 14).

Similar statement is also found in Surat al-Baqarah: 233. 
The breastfeeding time, which lasts until 2 years, will help children grow well physically and mentally since the period is crucial for the children. Today, it popular as exclusive breast milk. This term refers to the feeding of pure breast milk to the infant for the first six months without any complementary food. The feeding of pure breast milk is highly recommended because the nutrition of the milk is beneficial for developing the infant's brain cells (Dacholfany \& Hasanah, 2018).

The breastfeeding for two years benefits the children's growth, yet providing it longer gives different results. According to SWD, children who are breastfed too long will develop poor characters, such as lazy, stupid, and less apprehensive because they are only fond of eating and drinking.

On the contrary, the children who are weaned between 7 to 17 months will be cautious, smart, and more apprehensive. Apprehension, or known as tapa brata, is a means for the Javanese to bring themselves closer to the Almighty. Wedhatama by Mangkunegara IV explains:

"Absorb the prominent deeds, for those who live in the Land of Java (Javanese society), the noble people in Mataram (Panembahan Senapati) is very serious in striving or learning, and controlling the desire, by being apprehensive, both in the day and in the night, and always do the good deeds to the mankind" (Susetya, 2016: 47-48).

The description of apprehension for shaping the fundamental human characters is modeled by Panembahan Senapati, the leader of the Mataram Kingdom, through the control over desire, the conduct of tapa brata, and good deeds to others. Somebody who performs tapa brata will do cegah dhahar lawan nendra (decreasing the intensity of eating and sleeping), so his/her desire will also be decreased. It is the great ancestors' value that leads people to be a prominent figure.

\section{The Stages of Child Character Formation}

After the breastfeeding is ended, children will be in the toddler period (under five years old) and the childhood (seven years old). When they are seven years old, the procedures of teaching an ethic are: (1) explaining the good and the right things; (2) directing them to the right behaviors (the prominence of life); and (3) adjusting the teachings to their behaviors without any force. These procedures should be performed on the daily basis. The following Javanese traditional poem explains: 
Lan maning pituturingwang, lamun sira asisiwi, yen wus umur pitung warsa, awit tuntunen wruh mangi, dedalan mrih utami, nanging ta aja kesusu, sapakantuking boocah, aja sira perdi-perdi, saben dina kudu den telatenana (Pupuh Sinom, n.d: 7). "And this is my advice, if you have a child, when your child is seven years old, start teaching the good and the right things, lead them to the right behaviors, namely the path of life prominence. However, such teaching should not be in hurry; instead, the teaching should be adjusted to the behaviors of the child, do not force the child too much, just teach the child every day diligently" (Darweni, 2017: 6).

Concerning the character formation in the age of 7-11 years old, according to Piaget, children in this age group have already reached the Operational Concrete Development. This stage is the beginning for the children to start reasoning. In this stage, they have understood logical that can be implemented in the concrete problems. Suppose the children should deal with the contradiction between the mind and the perception. In that case, the children will be able to make logical decisions, instead of perceptual decisions as they experience in the previous stage.

The subsequent stage of child character formation occurs when the children reach the age of nine. In this stage, the procedures of building the child characters are: (1) guiding the children to the path of righteousness; (2) getting the children to the right track of education; (3) trying sincerely, (4) inviting the children to review the teachings of the Prophet Muhammad slowly; (5) teaching the children to speak politely; and (6) being patient with the children so they will not feel that they are being forced. The teaching concept for the nine years old children is mentioned in the following Pupuh Sinom:

"When the children are already nine years old, start the teaching process by leading the children to the path of righteousness, getting the children to the right track of education, trying sincerely, inviting the children to understand the teachings of Prophet Muhammad slowly. Teaching the children to speak politely as well, and be patient so that the children will not feel that they are being forced" (Darweni, 2017: 6).

Then, when they are 11 years old, the character formation is made by: (1) getting a total control over the children without any mercy; and (2) educating them to the righteousness. These procedures are found in the following Javanese traditional poem:

"When the children are 11 years old, they should be completely controlled, there should be no mercy, although they might be the only one in the families, while they are young because when they get older the education will be more difficult and, thus, it might not be successful especially, if it is without great 
effort. Therefore, education to the path of righteousness becomes an important attempt" (Darweni, 2017: 6).

When the children are 12 years old, (1) it is permissible to beat them, if they deny doing a good deed; and (2) it is not suggested to spoil them. These procedures are written in the following Javanese traditional poem:

"That is the way to educate the children. When the children are twelve years old, but they deny the teachings of righteousness, it will be better to beat them, but do not beat them hard. If the children still deny the teachings of righteousness, then beat them. It is the way to educate the children; if the children's education is late, their development will be at a disadvantage. Therefore, teach the children about the path of righteousness while they are still young" (Darweni, 2017: 6).

Intuitively, parents will always work hard for the happiness of their children, as mentioned in the following Javanese traditional poem.

Abot entheng datan ana, tinimbang kalawan siwi, suka susah datan ana, tinimbang kalawan siwi, lewih sukaning siwi, datan liyan sangking sunu, luwih susah jroning tyas, tan lyan sangking ing siwi, luwih abot tan dadya boboting anak (Pupuh Sinom, n.d, : 9).

"The parents work lightly and hard for the sake of the happiness of their children, whether they are happy or sad is fine because they work for the happiness of their children. They do every single thing for their children despite of the hardship they face; this is because they only care about the happiness of the children" (Darweni, 2017: 7).

Educating children is not easy. When they ask for something and the parents cannot afford to buy it, they will certainly cry. It sometimes urge parents to steal to fulfill what they ask. Therefore, the parents are prohibited from spoiling the children. If the children become criminal, parents will be in a serious problem. On the other hand, if they are happy, the parents will also be happy. This poem explains:

Susahe wong anak-anak, kalamun den jajaluki, yen pinuju during ana, anake mangka anangis, tambuh rasaning ati, yen terkadang nekat mandung, labete tinangisan, enthenge wong asi siwi, saben bengi lunga mring canthang balungan (Pupuh Sinom, n.d. : 10). "The difficulties in taking care of the children, when they ask for something, if the parent does not have what they are asking for, meanwhile the children are crying, this will be very difficult for the parents' heart, sometimes it leads parents to steal. Then the happiness of having children, if they achieved fortune without any payment" (Darweni, 2017: 7).

The following poem mentions:

Dene yen anake ala, bapa tan wurung kacangking, yen anake tuk nugraha, bapa biyung milu mukti, nadyan tan milu mukti, andulu bungah kalangkung, mila padha yen yitna, mring anak ja dumeh asih, tuduhena sabarang karya utama (Pupuh Sinom, n.d., : 13). 
"If the children have bad behaviors, they will stain the name of their father, if the children gain happiness, their father and mother will also be happy. Although they do not take a part in the children's happiness, seeing the children happy, the parents will be very happy. Therefore, the parents should be careful in taking care of the children, children should not be spoiled, and children should be guided toward the path of righteousness" (Darweni, 2017: 8) Therefore, the procedures of introducing the righteousness to the children are: (1) providing a meticulous explanation about the path of righteousness; (2) delivering the manners; (3) providing guidance clearly and carefully; and (4) displaying the bad behaviors. These procedures are explained in the following poem:

Apan marang kabecikan, wijang-wijangen den titi, miwah tata kramanira, anak kang wajib nglakoni, den cetha den ati-ati, supaya haywa kaliru, myang kang ala tuduhna, den dumunung amrih eling, yen wes weruh nuli age tutupana (Pupuh Sinom, n.d., : 13) "In terms of righteousness, explain the path of righteousness meticulously, introduce the manners as well, because it is compulsory for the children to implement the path of righteousness, guide the children clearly and carefully so that the children do not make any mistakes. In terms of bad behaviors, these behaviors should also be displayed to the children to understand and memorize it. If the children already have sufficient understanding, then let them keep them as their memories" (Darweni, 2017: 8).

In general, parents have four responsibility with their children and grandchildren: (1) providing a good education; (2) treating them when they are sick; (3) teaching them about farming activities; and (4) praying for their goodness. These are explained in the following Javanese traditional poem:

Iku mungguh duga-duga, yen arsa amrih basuki, mila gonang-gonang tuwa, patang prakara kang wajib, kang dhingin mituturi, anak putu mrih rahayu, nyembur ping tiganira, mring anak putu yen sakit, ngelu mules wong tuwa pan kuwajiban. (Pupuh Sinom, n.d.,: 14).

"Those are the ways of salvation in this life. Thereby, parents are entitled with four responsibilities, first, educating their children and grandchildren so that they will be save in their life, second, treating them when they are sick, dizzy, having abdominal pains, these are the duties of the parents" (Darweni, 2017: 9). Nenandur ping tiganira, sabarang ywa milih wiji, lamun non atuwuhira, kinarya neng eneng siwi, kaping sekawaneki, wong tuwa becik pitekur, wong tuwa kuwajiban, dedana maring Hyang Widhi, andongakna marang anak putonira (Pupuh Sinom, n.d., : 15). "The third, teaching them to plant any seeds, without selection, so when the seeds completely grows, the fruits can be eaten together with the children. The fourth, parents should contemplate, ask, and pray to the God Almighty for their sake" (Darweni, 2017: 9). 


\section{The Principles of Educating Children}

Principally, educating children (especially the little ones) should be performed by: (1) showing the path of righteousness; (2) being steady during the education process regarding the children's capability; (3) being persistent and continuous with the education process; and (4) being careful for the long process of education. These principles are explained in the following Javanese traditional poem.

Wit ning kaya mengkonoa, kudu pedhes ing pamidih, lamun kasep dadi baya, dene mupung misih cilik, wruhna dadalan becik, nanging ta aja kasusu, sapekantuk kewala, pasthi kudu nelateni, datan beda lawan wong anambut karya (Pupuh Sinom, n.d., : 21).

For such things, you have to work harder. Because if it is too late, it brings about negative consequence. Thereby, when the children are still young, show them the path of righteousness, but do not be in hurry, adjust to their capability, be persistent and continuous. It is the same as the way of people working (Darweni, 2017: 12)

Kudu lirih kudu lawas, mrih rapet don-adoneki, myang becik ing wawangunan, tan beda kalawan bayi, winuruk den susoni, lan winuruk mangan sekul, lawas-lawasing dina, bayi gedhe saya ngreti, aja sira ngarani takdir Hyang Suksma (Pupuh Sinom, n.d., : 21).

It should be performed carefully, and it takes a long process, so all aspects will be well-maintained, and the results will be good. The way is similar to take care of the baby, at the beginning, the baby is taught to breastfeed from the mother, and then the baby is taught to consume rice, as time passes by, the baby grows older and understands. This is the reality, so do not take all things like the fate destined by Lord the Almighty (Darweni, 2017: 13)

\section{Advice from the Parents to the Children}

One of the parents' important advices to the children is about controlling desire, especially the desire to eat and sleep. According to SWD, indulging the desire of eating and sleeping is considered misconduct. The advice is written in the following Javanese traditional poem:

Eling-elinga ta kaki, aja sok angumbar hawa, kang ora becik dadine, angel lakune ngagesang, kang amrih kautaman, aja pijer mangan turu, satemah nora prayoga (Asmaradana, n.d.,: 18)

"Remember this, my children, do not indulge your desire, because the result will be bad, your life will be difficult, you will have difficulties in attaining happiness. Do not eat or sleep too much, because both of them are misconduct" (Darweni, 2017: 33).

The following Javanese traditional poem mentions that people who like eating and sleeping too much will become impatient and lazy. They have the 
following traits: (1) being fond of stealing; (2) never keeping any promise; (3) speaking too much and being lazy to work:

Luwange wong doyan guling, nora sareh tur sukanan, sarta adoh daulate, luwange wong doyan mangan, titiga watekira, ambeler linyok gadebus, kalawan sukmaning karya (Asmaradana, n.d.,: 19)

"People who only like eating and sleeping will usually be impatient, lazy, and far away from their fortunes. People who like overeating usually have these three traits: fond of stealing, never keeping any promise, and talking too much and lazy to work" (Darweni, 2017: 33).

In addition, people who are too full cannot spend less time sleeping and their heart will be dark. The statement can be found in the following Javanese traditional poem:

Wateking wong kurang guling, sinung padhang jroning manah, lamun sira lungguh dhewe, gampang sakeh kang sinedya, wong amaregi pangan, tan miyat ngurangi turu, dadya peteng jroning manah (Asmaradana, n.d.,: 20).

"The heart of the people who want to decrease their sleep time is pure. When they sit alone, many ideas and expectations appear. On the other hand, people who overeat and unable to balance their sleeping time will have a dark heart" (Darweni, 2017: 34).

The above poem explains that people who eat less and sleep less will have a pure heart and many ideas and expectations come up. Then, the following Javanese traditional poem explains specifically that those who eat less and sleep less will attain: (1) convenience in terms of clothes and food; (2) discernment; (3) influence; and (4) subtle vision:

Sing sapa angirangirangi, anyegah turu lan mangan, lami-lami pinanggihe, sinung sandhang sinung pangan, tur sinung pangawikan, akathah daulatipun, lan sinung tingal kang lembat (Asmaradana, n.d., : 19)

"Those who can eat less and sleep less will eventually gain convenience in terms of clothes and food, and they will internalize discernment, gain influence, and also gain subtle vision" (Darweni, 2017: 34).

As mentioned, the great values in the SWD are integrated in the Islamic teachings. For example, the fact that breastfeeding period should ideally last in the age two is also suggested in the Qur'an. Qur'an refers breastfeeding as al-radha'a. Linguistically, the meaning of al-radha'a is breastfeeding, and this term applies to both women and female animals. Terminologically, the meaning of al-radha'a is breastfeeding the baby whose age is below two years old (Ismail, 2018). Furthermore, Ismail (2018) explains that the term al-radha'a is repeated for 10 times with multiple derivations in the Qur'an and it is distributed in 5 Surat: (1) Q.S. Al-Baqarah [2]:233; (2) Q.S. Al-Nisa' [4]:23; (3) Q.S. Al-Hajj [28]:7; (4) Al-Qashash [28]:7 and 12; and (5) Q.S. Al-Thalaq [65]. Thereby, 
psychologically, the children who are breastfed for two years and weaned are different from those who are breastfed for more than two years in terms of characters. The difference is asserted in both SWD and the Qur'an. SWD explains that those who are breastfed for the whole two years will have a good personality and will be independent, and those who are breastfed more than two years will be less confident and will be indecisive in their adolescence.

\section{Conclusion}

SWD proposes the urgency of child character formation with apprehension as the main character. The formation of the child character, according to the text, starts from the infancy through weaning them from their breastfeeding between seven and seventeen months old. At the age of seven, they should be introduced to the path of righteousness by: teaching them about the good and the right deed; leading them to the right behaviors (the path of righteousness); adjusting the education process to the children's behaviors without any force; and being persistent in teaching the path of righteousness on the daily basis. Then, at the age of nine, the procedures of building the child characters are: teaching them about the good and the right things; getting them on the right track of the education process; putting the sincere efforts in education; inviting them to review the teachings of the Prophet; teaching them to speak politely; and being patient with the education process, so they understand that they are not forced. At the age of eleven, the character formation of the children should be pursued by: controlling the children without showing any mercy; educating them towards the path of righteousness. Eventually, when they are twelve years old, the character formation should be achieved unless parents are allowed to beat them.

\section{References}

Astuti, E. P. (2018). Paham Wahdatul Wujud Syekh Ahmad Al Mutamakkin dalam Serat Cebolek Karya Yasadipura I. IAIN Surakarta.

Behrend, T. E. (1993). Manuscript production in nineteenth-century Java; Codicology and the writing of Javanese literary history. Bijdragen Tot de Taal, Land-En Volkenkunde, Manuscripts of Indonesia, 149, 407-437.

Behrend, T. E. (1999). The writings of K.P.H. Suryanagara; Shifting paradigms in nineteenth-century Javanese thought and letters. KTLLV, 155, 388-415. 
Dacholfany, M. I. \& Hasanah, U. (2018). Pendidikan Anak Usia Dini menurut Konsep Islam. Jakarta: Amzah.

Darweni. (2017). Buku Ajaran Darmawiyata. Surakarta: Perpustakaan Reksopustoko.

Darweni. (2016). Deskripsi Naskah Piwulang. Surakarta: Rekso Pustoko Puro Mangkunegara.

Day, A. (1978). Babad Kandha, Babad Kraton and Variation in. Bijdragen Tot de Taal,Land-En Volkenkunde, 134, 433-450.

Deswijaya, A; Nurnaningsih, \&Tri W. (2016). Pendidikan Karakter di dalam Serat Kridhawasita. Jurnal Pendidikan, 25(1).

Drewes, G. W. J. (2013). The struggle between Javanism and Islam as illustrated by the Serat Dermagandul. Bijdragen Tot de Taal-, Land-En Volkenkunde / Journal of the Humanities and Social Sciences of Southeast Asia. https:// doi.org/10.1163/22134379-90002925

Ekowati, V. I., Wulan, S. H., Handoko, A., \& Insani, N. H. (2017). Pendidikan Karakter dalam Iluminasi Naskah Babad Pecinna. Jurnal Penelitian Humaniora, 22(1), 32-44.

Endraswara, S. (2008). Metodologi Penelitian Sastra: Epistemologi, Model, Teori dan Aplikasi. Yogyakarta: Media Pressindo.

Eriyanto (2011a). Analisis Isi: Pengantar Metodologi untuk Penelitian Ilmu Komunikasi dan Ilmu-Ilmu Sosial Lainnya. Jakarta: Prenada Media Group.

Eriyanto (2011b). Analisis Isi: Pengantar Metodologi untuk Penelitian Ilmu Komunikasi dan ilmu-ilmu sosial lainnya. Kencana Prenada Media Group..

Florida, N. K. (2000). Javanese Literature in Surakarta Manuscripts, Manuscripts of The Mangkunagaran Palace. Volume 2. Ithaca, New York: Southeast Asia Program Cornell University (SEAP).

Ismail, H. (2018). Syariat Menyusui dalam Alquran (Kajian Surat Al-Baqarah Ayat 233). Jurnal At-Tibyan: Jurnal Ilmu Alquran Dan Tafsir, 3(1), 69. https://doi.org/10.32505/tibyan.v3i1.478

Khasani, A. (2015). Sejarah Sastra Jawa. Kompasiana. https://www.kompasiana. com/khasani/551f83cba333114340b65b81/sejarah-sastra-jawa 
Kholil, A. (2007). Islam Jawa (Sufisme Dalam Tradisi dan Etika). El- Harakah, 9(2), 87-99. https://doi.org/https://doi.org/10.18860/el.v9i2.4644

Krippendorff, K. (2004). Content Analysis; An Introduction. London: SAGE Publications, Inc.

Maknun, M. L. (2017). The Education of Javanese Characters in Serat Wasitawala. Analisa: Journal of Social Science and Religion, 2(2), 214-233. https://doi.org/10.18784/analisa.v2i2.510

Masfiah, U. (2018). Nilai Pendidikan Karakter dalam Naskah Serat Munasiat Jati. In Nilai-Nilai Pendidikan dalam Manuskrip Jawa. Yogyakarta: Bumi Intaran.

Mulyono \& Sahlan, A. (2012). Pengaruh Islam terhadap Perkembangan Budaya Jawa: tembang Macapat. El Harakah 14(1), 101-114. https:// doi.org/10.18860/el.v0i0.2196

Mustolehudin (2018). Nilai-Nilai Pendidikan Karakter dalam Serat Wirid Wedharaning Cipta Sasmitaning Ngilmi. In Nilai-Nilai Pendidikan dalam Manuskrip Jawa. Yogyakarta: Bumi Intaran.

Naif, F. (2016). Seh Amongraga (Tokoh Mistik Jawa Dalam Serat Centhini). Reffeksi, 16(1).

Purwadi (2015). Pemikiran Ranggawarsita sebagai Bahan Ajar Pendidikan Karakter. Jurnal IKADBUDI, 4(10). https://doi.org/10.21831/ikadbudi. v4i10.12026

Ras, J. (2014). Masyarakat dan Kesusastraan di Jawa. Jakarta: Yayasan Obor Indonesia.

Retnowati, D. (2020). Nilai Luhur Serat Wulangreh Pupuh Gambuh Membangun Karakter Generasi Milenial, 3(1), 1-11.

Ricci, R. (2009). Conversion to Islam on Java and the "Book of One Thousand Questions." Bijdragen Tot de Taal, Land-En Volkenkunde.

Ridlo, S. (2018). Nilai-Nilai Pendidikan dalam Naskah Suluk Seh Ngabdul Salam. In Nilai-Nilai Pendidikan dalam Manuskrip Jawa. Yogyakarta: Bumi Intaran. 
Robson, S. . (1979). Notes on the early Kidung literature. Bijdragen Tot de Taal, Land-En Volkenkunde, 135, 508-519.

Rubaidi (2019). Javanese Islam ; a Blend of Javanese Culture and Islamic Mysticism Viewed From Post-Colonial Perspective. El Harakah, 21(1), 19-36. https://doi.org/https://doi.org/10.18860/el.v21i1.6066

Simuh (1999). Sufisme Jawa: Transformasi Tasawuf Islam ke Mistik Jawa. Yogyakarta: Yayasan Bentang Budaya.

Suhanjati, S. (2004). Ijtihad progresif Yasadipura II dalam akulturasi Islam dengan budaya Jawa. Yogyakarta: Gama Media.

Susetya, W. (2016). Empat Hawa Nafsu Orang Jawa. Jakarta: Buku Seru.

Wibawa, S. (2013). Nilai filosofi jawa dalam Serat Centhini. Litera, 12(2), $328-344$.

Wiratini, G. A. K. (2017). Nilai-Nilai Karakter yang Terdapat dalam Serat Wedatama. Jurnal Penelitian Agama Hindu, 1(2), 153-160.

Yahya, I. (2017). Review Seminar Hasil Penelitian Nilai-Nilai Pendidikan dalam Manuskrip Keagamaan. Surakarta. 
